\title{
Effect of Thyme, Cumin and Anise on the Formation of Acrylamide in Some Bakery Products
}

\author{
Tesby M R. Lotfy ${ }^{1}$, Neveen F. Agamy ${ }^{2}$, Neveen A. El-Wardany ${ }^{1}$, \\ Nashwa M. Younes ${ }^{1}$ \\ Dep, Home Economics, Faculty of Specific Education, Alexandria University \\ Dep, Nutrition, High institute of Public Health, Alexandria University
}

\begin{abstract}
Background: Bakery products account for about $20 \%$ of human exposure to acrylamide. Many herbs and spices have been recognized to have medicinal properties and beneficial impact on health such as antioxidants activity. Objective: The aim of this study was to determine the effects of adding thyme, cumin and anise as antioxidants to reduce acrylamide content in Arabic bread, Paton salé and Cressina. Methods: Twelve samples were prepared for chemical analysis to determine antioxidant activity, acrylamide content, flavonoids, total phenols and essential oils. Bakery products were conducted for sensory evaluation. Results indicated that the percentage of antioxidant activity increased by adding thyme, cumin and anise. The highest percentage of antioxidant activity was detected in patonsalé with anise, cressina with cumin, arabic bread with anise $(40.77 \pm 0.53,39.43 \pm 0.36,34.35 \pm 0.15$ respectively) while the lowestwas detected in samples without additives. In contrast the content of acrylamide decreased in arabic bread with anise, patonsalé with anise, and cressina with cumin $(0.0 \pm 0.0,0.30 \pm 0.0,0.43 \pm 0.06$, resp $)$ while increased in samples without additives. Conclusion: The results confirmed that thyme, cumin and anise minimized and alleviated the formation of acrylamide in bakery products and increased the activities of antioxidant. This study recommends increasing the usage herbs and spices to foods, especially bakery products.
\end{abstract}

Key words: acrylamide - antioxidant activities-herbs-spices- bakery products.

\section{INTRODUCTION}

Many workers showed that Acrylamide is found in all baked goods and the most important products are bread, crisp bread, gingerbread, crackers, cookies, and biscuits (Friedman, 2003). khalaf Allah, (2014) reported that the average student acrylamide intake derived from balady bread was $166.5 \mu \mathrm{g} / \mathrm{month}$ and noting that the content of acrylamide in balady bread is low but intake by students from it is relatively high also, it was found that $65.25 \%$ of students consumed patonsalé and most of them $(61.5 \%)$ preferred buying from the bakery.

The risk of acrylamide to health and its toxic properties neurotoxicity, genotoxicity, carcinogenicity and reproductive toxicity were demonstrated by Scientific Committee on Toxicity, Ecotoxicity and the Environment (Zaied et al., 2016; Keramat et al., 2011). IARC (1994) Showed that (AA) occurs in foods containing carbohydrates prepared by heating above $120^{\circ} \mathrm{C}$, frying, grilling, and baking. (AA) is not formed during boiling or microwaving. Cereal food product stand to have the highest amounts of (AA) among commonly consumed foods (Clause et al., 2008).

Many spices have been recognized to have medicinal properties and beneficial impact on health,e.g. antioxidant activity, digestive stimulation action, antiinflammatory, antimicrobial, hypolipidemc and anticarcinogenic potential (Aaby, 2004). Herbs are used in many domains, including medicine, nutrition, flavoring, beverages, dyeing, repellents, fragrances, cosmetics (Djeridanne etal., 2006). Antioxidants such as phenolic compounds, flavonoids, vitamins, and phenolic extracts from various spices have been reported as inhibiting acrylamide formation (Ou et al., 2010; Kotsiou et al., 2011).

There are many pathways of acrylamide formation, asparagine needs a carbonyle compound to be converted to acrylamide.The Carbonyle can come from multiple sources. Due to the diversity of antioxidants in structure and properties and complexity of the reaction, different antioxidants are involved in different reactions during the process of maillard reaction, Thus causing different effects towards acrylamide formation.It seems that whether the carbonyl is available in both A\&B pathways depend on the functional group in the B-Position to the nitrogen atom. The presence of a hydroxyl group favors the rearrangement from azomethine yield to the decarboxylatedAmadori product to afford acrylamide (pathway A). $\alpha, \beta, \gamma, \delta$-diunsaturated carbonyl group and $\alpha$ - dicarbonyl groups may play a key role in pathway B. As for carbonyl group,aldehydes are more reactive than ketones.Also ,apathway named acrolein pathway was put up as shown in figure1(Yasuhara et al., 2013).

This study aims at evaluating the effect of adding thyme, cumin and anise on the formation of Acrylamide in Arabic bread, Patonsalé and Cressina. 


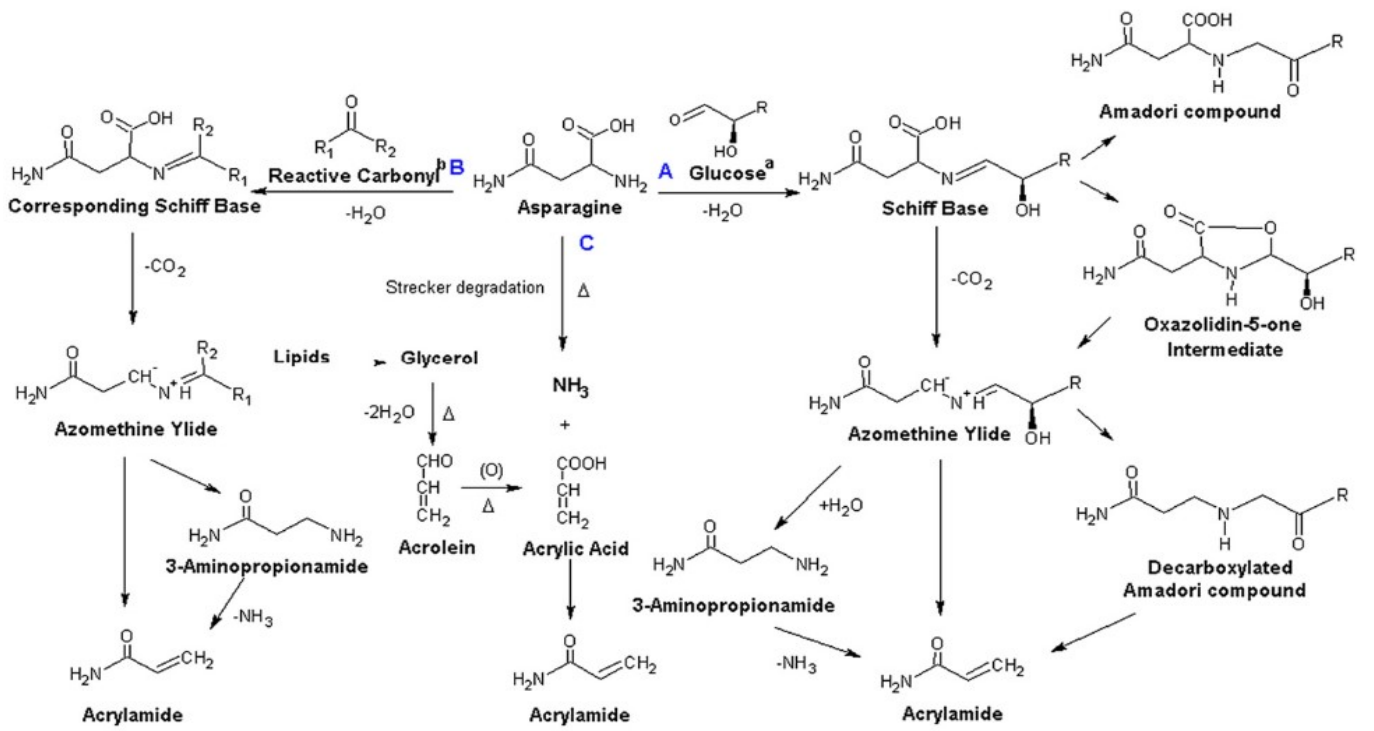

Figure 1: Pathways formation of acrylamide from asparagine. a: $\alpha$-hydroxy cabonyl compound, take glucose as an example. b: R1 or R2 has an $\alpha, \beta, \gamma, \delta$-di unsaturated carbonyl group or $\alpha$-carbonyl, or R1 or $R 2=H$ sometimes(Jin et al.,2013).

\section{MATERIALS AND METHODS}

\section{Study setting}

The study was conducted at the laboratory of Nutrition Department, Faculty of Specific Education, The Central Laboratory of The high Institute of Public Health, and The Central Laboratory of Faculty Agriculture, Alexandria University.

\section{Materials}

Dry powder of thyme, cumin, and anise and other materials were purchased from Alexandria local market, Egypt. All other chemicals and reagents used were analytical grade and obtained from EL- Goumhorya Company, Egypt.

\section{Preparation of bakery products:}

Bakery Products including arabic bread, patonsalé and cressina. Each Bakery products were prepared using three natural additives except control were prepared according to recommended ingredients (3 replicates for each). 3\% of spices and herbs / $100 \mathrm{~g}$ flour were added to different bakery products and were prepared according to the methods mentioned by (Saba, 1991).

Sensory evaluation:

The sensory characteristics were evaluated according to(Stone et al 2012) by 20 staff members and students of Faculty of Specific Education, Alexandria University for pilot study to select the highest acceptability score in samples with (1, 3 and $5 \%$ ) of herbs and spices powder adding to bakery products to be ready to chemical analysis. Parameters were taste, color, texture, odor and the overall acceptability. The 9- point hedonic scale with a scale ranging from 1 (representing extremely dislike) to 9 (representing extremely like).

Analytical methods

Proximate analysis including moisture, Crude protein, crude fat, and total ash were determined according to (AOAC, 1995) Carbohydrates values were derived empirically after subtracting the other components.

Acrylamide in bakery products:

Acrylamide content was detected by HPLC according to the method of (Agamy, 2013) with some modifications.

Antioxidants activity (free radical scavenging activity assay):

Free radical scavenging activity assay was performed according to (Williams et al 1995).

\section{Total flavonoids content (TVC):}

Total flavonoids content (TVC) extraction was carried out using the method of (Siddhuraju and Becker, 2003).

Total phenolic content (TPC):

Total phenolic content (TPC) was estimated according to the Folin-Ciocalteu method using gallic acid as the standard (Makkar et al 1997).

Volatile oils (essential oils) content (EOs):

Volatile oils content was determined according to the method of (Egan et al., 1981).

\section{Statistical analysis:}

Analyses of variance (ANOVA) was conducted to determine significant differences among groups, Statistical significant was considered at $<0.001$. All statistical analyses were carried out using the Statistical analysis System program (Kotz, 2006; Kirkpatrick and Feeny, 2013). 


\section{RESULTS AND DISCUSSION}

\section{Sensory evaluation of bakery products}

Sensory score when adding 1, 3 and $5 \%$ of herbs and spices $/ 100 \mathrm{~g}$ of flour to bakery products evaluated by 20 persons to select the highest score of acceptability in these samples are shown in Table (1).

Table 1: Sensory scores of bakery products containing thyme, cumin, and anise.

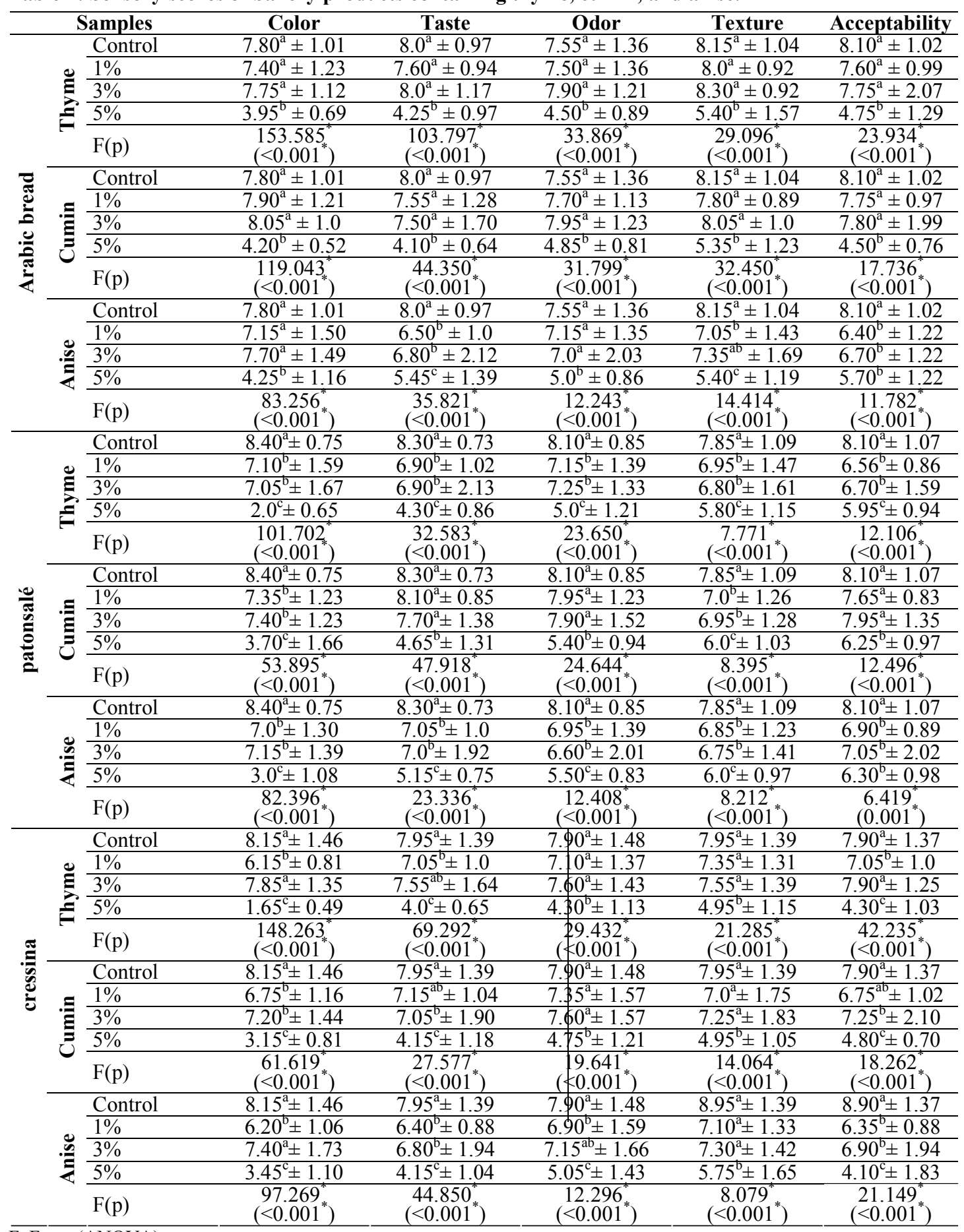

$\overline{\mathrm{F}: \mathrm{F}}$ test (ANOVA)

*: Statistically significant at $\mathrm{p} \leq 0.05$

Different superscripts are statistically significant.

Data was expressed by using mean \pm SD. 
Sensory score of Arabic bread samples with thyme, cumin and anise are shown in Table (1). It can be observed that the highest mean value of overall acceptability of Arabic bread was (8.10 \pm 1.02) for control sample followed by $1,3,5 \%$ of thyme $(7.60 \pm 0.99,7.75 \pm 2.07,4.75 \pm 1.29$, respectively). Taste, color, odor, texture and over all acceptability of Arabic bread were significantly ( $\mathrm{p} \leq$ 0.05 ) affected by adding different doses of thyme to samples of Arabic bread compared to the control sample.

It can be indicated that taste, color, odor, texture and over all acceptability of Arabic bread were significantly $(\mathrm{p} \leq 0.05)$ affected by adding different doses of cumin to samples of Arabic bread compared to the control. Besides, the highest mean value of overall acceptability of Arabic bread was $(8.80 \pm 0.41)$ for control sample followed by 1,3 , $5 \%$ of cumin $(7.75 \pm 0.97,8.80 \pm 1.99,5.50 \pm 0.76$, respectively).

Taste, color, odor, texture and over all acceptability of Arabic bread were significantly ( $\mathrm{p} \leq$ 0.05 ) affected by adding different doses of anise to samples of Arabic bread compared to the control sample. Besides, The highest mean value of overall acceptability of Arabic bread was $8.80 \pm 0.41$ for control sample followed by $1,3,5 \%$ of anise $(6.70 \pm$ $1.22,7.70 \pm 1.22,5.70 \pm 1.22$, respectively).

Results indicated that adding $3 \%$ of thyme, cumin and anise led to increase in the level of the overall acceptability in Arabic bread compared to adding other concentrations.

The sensory score of Patonsalé samples with thyme, cumin and anise shown in Table (1). It was indicated that the highest mean value of overall acceptability of Patonsalé was $8.10 \pm 1.07$ for control sample followed by $1,3,5 \%$ of thyme ( 6.70 $\pm 0.86,7.60 \pm 1.59,5.95 \pm 0.94$, respectively). Color is one of the most important parameters in sensorial evaluation (Lotfy and Nawar, 2014). Taste, color, odor, texture and overall acceptability of Patonsalé were significantly affected $(\mathrm{p} \leq 0.05)$ by adding different doses of thyme to samples of Patonsalé compared to the control. It can be observed that Taste, color, odor, texture and overall acceptability of Patonsalé were significantly affected $(\mathrm{p} \leq 0.05)$ by adding different doses of cumin to samples of Patonsalé compared to the control. Besides, The highest mean value of overall acceptability of Patonsalé was $8.80 \pm 0.41$ for control sample followed by $1,3,5 \%$ of cumin $(7.65 \pm 1.35,7.95 \pm$ $0.83,6.25 \pm 0.97$, respectively).

It can be indicated that Taste, color, odor, texture and overall acceptability of Patonsalé were significantly affected $(\mathrm{p} \leq 0.05)$ by adding different doses of vanilla to samples of Patonsalé compared to the control. Besides, the highest mean value of overall acceptability of Patonsalé was $(8.80 \pm 0.41)$ for control sample followed by $1,3,5 \%$ of anise $(6.90 \pm 2.02,7.05 \pm 0.89,6.30 \pm 0.98$, respectively).

Sensory score of Cressina samples with thyme, cumin and anise shown in Table (1). It can be observed that the highest mean value of overall acceptability of Cressina was $(7.90 \pm 1.37)$ for control sample followed by $1,3,5 \%$ of thyme (7.05 $\pm 1.0,7.90 \pm 1.25,4.30 \pm 1.03$, respectively). Taste, color, odor, texture and over all acceptability of Patonsalĕ were significantly $(\mathrm{p} \leq 0.05)$ affected by adding different doses of thyme to samples of Cresina compared to the control. It can be indicated that taste, color, odor, texture and overall acceptability of Cressina were significantly ( $\mathrm{p} \leq$ 0.05 ) affected by adding different doses of cumin to samples of Cressina compared to the control. Besides, the highest mean value of overall acceptability of Cressina was $(8.80 \pm 0.41)$ for control sample followed by $1,3,5 \%$ of cumin $(6.75$ $\pm 2.10,7.25 \pm 1.02,4.80 \pm 0.70$, respectively) .

Recent years have seen increased interest from consumers, researchers, and the food industry in how food products can help maintain health; and the role that diet plays in the prevention and treatment of many illnesses. From the present results the samples of 3\% was selected to perform the chemical analysis because it was showed that high score of sensory quality of bakery products.

\section{Proximate analysis of bakery products}

Proximate analysis of Arabic bread samples containing 3\% of thyme, cumin and anise compared to the control are shown in Table (2). It is important to measure the moisture content in breads because of its potential impact on the sensory, physical and microbial properties of the bread (Olaoye et al., 2006). It can be observed that the content of moisture was $(12.15 \pm 0.11)$ for control and increased to be $(12.26 \pm 0.15,12.33 \pm 0.07,12.74 \pm$ 0.25 ) for samples contained thyme, cumin and anise, respectively. The obtained results were in agreement with those reported by (Jooyandeh , 2009; Hussein et al., 2013; Okafore et al., 2012 )who found that moisture content of Arabic bread was (12.5, 11.65 and $12.30 \%$, respectively). Protein content of Arabic bread containing thyme, cumin and anise increased to be $(11.54,11.59$ and $11.66 \%$, respectively) compared to the control sample $(11.45 \%)$. The obtained results were agreement with these of (Mongi et al., 2011; Yıldız and Bilgiçli, 2012; Bakare et al.,2016; Hussein et al., 2013) who reported that protein content in bread were 10.9, 11.6, $10.42,12.05 \%$, respectively. On the other hand, the fat content of Arabic bread containing thyme, cumin and anise were significantly increased (1.83, 1.95 and $1.94 \%$ ) respectively compared to the control sample (1.78\%). These values agreed with the results of (Hussein et al, 2013; Okafore et al., 2012) who found that the fat contents were 1.81 , $1.30 \%$, respectively. 
Table 2: Proximate analysis of arabic breadsamples.

\begin{tabular}{lccccc}
\hline $\begin{array}{l}\text { Arabic } \\
\text { bread }\end{array}$ & $\begin{array}{c}\text { Moisture } \\
\text { Mean } \pm \text { SD }\end{array}$ & $\begin{array}{c}\text { Ash } \\
\text { Mean } \pm \text { SD }\end{array}$ & $\begin{array}{c}\text { Protein } \\
\text { Mean } \pm \text { SD }\end{array}$ & $\begin{array}{c}\text { Fat } \\
\text { Mean } \pm \text { SD }\end{array}$ & $\begin{array}{c}\text { Carbohydrates } \\
\text { Mean } \pm \text { SD }\end{array}$ \\
\hline Control & $12.15^{\mathrm{b}} \pm 0.11$ & $1.44^{\mathrm{a}} \pm 0.02$ & $11.45^{\mathrm{a}} \pm 0.22$ & $1.78^{\mathrm{b}} \pm 0.04$ & $73.19^{\mathrm{a}} \pm 0.14$ \\
\hline Thyme & $12.26^{\mathrm{b}} \pm 0.15$ & $1.45^{\mathrm{a}} \pm 0.02$ & $11.54^{\mathrm{a}} \pm 0.09$ & $1.83^{\mathrm{ab}} \pm 0.12$ & $72.92^{\mathrm{ab}} \pm 0.26$ \\
\hline Cumin & $12.33^{\mathrm{b}} \pm 0.07$ & $1.48^{\mathrm{a}} \pm 0.02$ & $11.59^{\mathrm{a}} \pm 0.08$ & $1.95^{\mathrm{a}} \pm 0.06$ & $72.65^{\mathrm{b}} \pm 0.15$ \\
\hline Anise & $12.74^{\mathrm{a}} \pm 0.25$ & $1.46^{\mathrm{a}} \pm 0.03$ & $11.66^{\mathrm{a}} \pm 0.05$ & $1.94^{\mathrm{a}} \pm 0.01$ & $72.20^{\mathrm{c}} \pm 0.31$ \\
\hline $\mathrm{F}$ & $7.844^{*}$ & 1.704 & 1.531 & $4.856^{*}$ & $10.309^{*}$ \\
\hline $\mathrm{p}$ & $0.009^{*}$ & 0.243 & 0.280 & $0.033^{*}$ & $0.004^{*}$ \\
\hline
\end{tabular}

F: F test (ANOVA)

$*$ : Statistically significant at $\mathrm{p} \leq 0.05$

Means with Common letters are not significant (Means with Different letters are significant)

Data was expressed by using mean $\pm \mathrm{SD}$.

The data in Table (2) record that the total ash contents of Arabic bread containing thyme, cumin, anise were $1.45,1.48$ and $1.46 \%$ respectively compared to the control sample (1.44\%). These values were agreed with results reported by Mongi et al; 2011 who reported that the ash content was $(1.15 \%)$, While disagreed with the results of (Y1ldz and Bilgiçli, 2012; Bakare et al; 2016 ) who found that the value of ash in bread ranged from 0.65, 0.47 and $0.48 \%$, respectively. The carbohydrates content of Arabic bread contains thyme, cumin and anise were significantly decreased to be 72.92 , 72.65 and $72.20 \%$, respectively compared to the control sample $(73.19 \%)$. Concerning the carbohydrates content of bread (Jooyandeh, 2009: Mongi et al.,2011). It was observed that the percent evenness $(63.25,75.71 \%)$ and this agree with the control sample. The results tabulated in Table (2) showed that there were significant differences among samples in the content of fat, moisture and carbohydrates, while there were no significant differences in protein and ash at $p \leq 0.05$. It can also be noticed that the high carbohydrates content of bread has a potential impact on Maillard reaction.

Proximate analysis of patonsalé samples containing $3 \%$ of thyme, cumin and anise compared to the control are shown in Table (3). The moisture content of Patonsalé containing thyme, cumin and anise were $2.75 \pm 0.31,2.95 \pm 0.36$ and $2.92 \pm 0.04$, respectively compared to the control sample ( $2.61 \pm$ 0.11 ). It can be observed that ash content of Patonsalē containing thyme, cumin and anise were
$(2.95 \pm 0.03,2.75 \pm 0.02$ and $2.65 \pm 0.43$, respectively) compared to the control sample (2.47 \pm 0.02).On the other hand, protein content of Patonsalě containing thyme, cumin and anise were $(11.37 \pm 0.02,11.80 \pm 0.05$ and $11.40 \pm 0.05$, respectively compared to the control sample ( 11.30 \pm 0.05 ). It can be noticed that fat content of Patonsalé containing thyme, cumin and anise were $5.44 \pm$ $0.02,5.50 \pm 0.43$ and $5.33 \pm 0.14$, respectively compared to the control $(5.26 \pm 0.09)$. Besides, the carbohydrates content of Patonsalé containing thyme, cumin and anise were $77.49 \pm 0.26,77.01 \pm$ 0.08 and $77.70 \pm 0.54$, respectively compared to the control sample $(78.36 \pm 0.14)$. The results tabulated in Table (3) showed that there were a significant differences among samples in the content of carbohydrates and protein, while there were no significant differences in fat, ash and moisture at $\mathrm{p} \leq 0.05$. It can also be noticed that the highest mean value of carbohydrates content so it was important to measure the carbohydrates content in Patonsalé samples because of its potential impact on Maillard reaction of bakery products and acrylamide formation.

Proximate analysis of Cressina samples containing $3 \%$ of thyme, cumin and anise compared to the control are shown in Table (4). It can be observed that the moisture content of Cressina containing thyme, cumin and anise were $4.69 \pm$ $0.07,4.88 \pm 0.04$ and $4.66 \pm 0.04$, respectively compared to the control sample $(4.30 \pm 0.15)$.

Table 3: Proximate analysis of patonsalé samples

\begin{tabular}{lccccc}
\hline Patonsalé & $\begin{array}{c}\text { Moisture } \\
\text { mean } \pm \text { SD }\end{array}$ & $\begin{array}{c}\text { Ash } \\
\text { mean } \pm \text { SD }\end{array}$ & $\begin{array}{c}\text { Protein } \\
\text { mean } \pm \text { SD }\end{array}$ & $\begin{array}{c}\text { Fat } \\
\text { mean } \pm \text { SD }\end{array}$ & $\begin{array}{c}\text { Carbohydrates } \\
\text { mean } \pm \text { SD }\end{array}$ \\
\hline Control & $2.61^{\mathrm{a}} \pm 0.11$ & $2.47^{\mathrm{b}} \pm 0.02$ & $11.30^{\mathrm{c}} \pm 0.05$ & $5.26^{\mathrm{a}} \pm 0.09$ & $78.36^{\mathrm{a}} \pm 0.14$ \\
\hline Thyme & $2.75^{\mathrm{a}} \pm 0.31$ & $2.95^{\mathrm{a}} \pm 0.03$ & $11.37^{\mathrm{bc}} \pm 0.02$ & $5.44^{\mathrm{a}} \pm 0.02$ & $77.49^{\mathrm{bc}} \pm 0.26$ \\
\hline Cumin & $2.95^{\mathrm{a}} \pm 0.36$ & $2.75^{\mathrm{ab}} \pm 0.02$ & $11.80^{\mathrm{a}} \pm 0.05$ & $5.50^{\mathrm{a}} \pm 0.43$ & $77.01^{\mathrm{c}} \pm 0.08$ \\
\hline Anise & $2.92^{\mathrm{a}} \pm 0.04$ & $2.65^{\mathrm{ab}} \pm 0.43$ & $11.40^{\mathrm{b}} \pm 0.05$ & $5.33^{\mathrm{a}} \pm 0.14$ & $77.70^{\mathrm{b}} \pm 0.54$ \\
\hline $\mathrm{F}$ & 1.235 & 2.627 & $81.293^{*}$ & 0.649 & $9.852^{*}$ \\
\hline $\mathrm{p}$ & 0.359 & 0.122 & $<0.001^{*}$ & 0.605 & $0.005^{*}$
\end{tabular}

F: F test (ANOVA)

*: Statistically significant at $\mathrm{p} \leq 0.05$

Different superscripts are statistically significant 
Table 4: Proximate analysis of Cressina samples

\begin{tabular}{lccccc}
\hline Cressina & $\begin{array}{c}\text { Moisture } \\
\text { mean } \pm \text { SD }\end{array}$ & $\begin{array}{c}\text { Ash } \\
\text { mean } \pm \text { SD }\end{array}$ & $\begin{array}{c}\text { Protein } \\
\text { mean } \pm \text { SD }\end{array}$ & $\begin{array}{c}\text { Fat } \\
\text { mean } \pm \text { SD }\end{array}$ & $\begin{array}{c}\text { Carbohydrates } \\
\text { mean } \pm \text { SD }\end{array}$ \\
\hline Control & $4.30^{\mathrm{c}} \pm 0.15$ & $1.96^{\mathrm{a}} \pm 0.03$ & $11.34^{\mathrm{b}} \pm 0.02$ & $11.20^{\mathrm{b}} \pm 0.06$ & $71.19^{\mathrm{ab}} \pm 0.20$ \\
\hline Thyme & $4.69^{\mathrm{b}} \pm 0.07$ & $1.96^{\mathrm{a}} \pm 0.03$ & $10.56^{\mathrm{c}} \pm 0.21$ & $11.32^{\mathrm{ab}} \pm 0.12$ & $71.47^{\mathrm{a}} \pm 0.26$ \\
\hline Cumin & $4.88^{\mathrm{a}} \pm 0.04$ & $1.35^{\mathrm{b}} \pm 0.02$ & $11.45^{\mathrm{b}} \pm 0.09$ & $11.41^{\mathrm{a}} \pm 0.11$ & $70.91^{\mathrm{b}} \pm 0.14$ \\
\hline Anise & $4.66^{\mathrm{b}} \pm 0.04$ & $1.96^{\mathrm{a}} \pm 0.03$ & $11.89^{\mathrm{a}} \pm 0.12$ & $11.44^{\mathrm{a}} \pm 0.09$ & $70.05^{\mathrm{c}} \pm 0.21$ \\
\hline $\mathrm{F}$ & $23.033^{*}$ & $359.683^{*}$ & $54.217^{*}$ & 3.632 & $26.381^{*}$ \\
\hline $\mathrm{p}$ & $<0.001^{*}$ & $<0.001^{*}$ & $<0.001^{*}$ & 0.064 & $<0.001^{*}$ \\
\hline
\end{tabular}

F: F test (ANOVA)

*: Statistically significant at $\mathrm{p} \leq 0.05$

Different superscripts are statistically significant

It can be noticed that ash content of Cressina containing thyme, cumin and anise were $1.96 \pm$ $0.03,1.35 \pm 0.02$ and $1.96 \pm 0.03$, respectively compared to the control sample $(1.96 \pm 0.03)$.

On the other hand protein content of Cressina containing thyme, cumin and anise were $10.56 \pm$ $0.21,11.45 \pm 0.09$ and $11.89 \pm 0.12$, respectively compared to the control sample (11.34 \pm 0.02$)$. Besides, fat content of Cressina containing thyme, cumin and anise were $11.32 \pm 0.12,70.91 \pm 0.14$ and $70.05 \pm 0.21$, respectively compared to the control sample (11.20 \pm 0.06). As shown in Table (4), carbohydrates content of Cressina containing thyme, cumin and anise were $71.47 \pm 0.26,70.91 \pm 0.14$ and $70.05 \pm 0.21$, respectively compared to the control sample $(71.19 \pm 0.20)$.

The results in Table (4) showed that there were significant differences among samples in the content of carbohydrates, protein, ash and moisture, while there were no significant differences in fat content at $p \leq 0.05$. It can also be noticed that the highest mean value of carbohydrates content so it was important to measure the carbohydrates content in Cressina samples because of its potential impact on Maillard reaction of bakery products and acrylamide formation.

Antioxidant activity and acrylamide content in studied bakery products

Antioxidant activity (\%) and acrylamide content $(\mathrm{mg} / 100 \mathrm{~g})$ in some bakery products with $3 \%$ of thyme, cumin and anise are shown in Table (5).

It was observed that, the highest score of total antioxidant of Arabic bread sample was containing anise $(34.35 \pm 0.15)$ followed by thyme (29.49 \pm $0.14)$ then samples containing cumin $(25.33 \pm 0.13)$. It is also noticed that the control sample had the lowest score $(12.63 \pm 0.15)$. Data of antioxidant activity belonging to Arabic bread containing anise are in agreement with the results of (Shojaii and Abdollahi., 2012) who reported that the most important compounds of anise seeds essential oils, anise seeds showed strong antioxidant activity. On the other side, the result indicated that Acrylamide recorded the lowest content in anise $(0.0 \pm 0.0)$ followed by thyme $(0.01 \pm 0.0)$ and cumin $(0.04 \pm 0.01)$. The control sample recorded the highest level of Acrylamide $(0.56 \pm 0.0)$, these results agreed with the results of Mills et al., (2009) who reported that the amount of acrylamide in different product such as bread ranged from 10 to $3200 \mu \mathrm{g} . \mathrm{kg}-1$ and bread toast ranged from 25 to $1430 \mu \mathrm{g} . \mathrm{kg}-1$ this score explains the denotation of the presence of relationship between high ratio of antioxidant activity in the three samples with the reduction of Acrylamide level in bread samples. These results indicated that there were significant increase $(\mathrm{p} \leq$ $0.05)$ in antioxidants activities and significant decrease $(\mathrm{p} \leq 0.05)$ in content of acrylamide among all samples. The results in Table(5) showed that , the highest percent of total antioxidant activity was found in Arabic bread with anise ,thyme and cumin , respectively compared to control while, the lowest content of acrylamide was found in Arabic bread with anise, thyme and cumin compared to control sample.

It is shown in Table (5) that the peak of totalantioxidants in Patonsalé samples was at the addition of anise $(40.77 \pm 0.53)$ followed by thyme $(31.74 \pm 0.50)$ and cumin came at the last order $(30.51 \pm 0.40)$ compared to the control $(24.58 \pm$ $0.36)$. With regard to levels of AA in the samples a decrease happened in AA levels compared to control sample. It was also noticed that, the most effective way to decrease AA levels was by addition of anise $(0.30 \pm 0.0)$ followed by thyme $(0.31 \pm$ $0.06)$ and cumin $(0.38 \pm 0.03)$. This explains the relation between total antioxidants and low levels of AA. These results indicated that there were a significant increase $(\mathrm{p} \leq 0.05)$ in antioxidants activities and a significant decrease $(p \leq 0.05)$ in content of acrylamide among all samples. The tabulated results showed that, the highest percent of total antioxidant activity was found in patonsalé with anise ,thyme and cumin ,respectively compared to control sample while, the lowest content of acrylamide was found in Patonsalé with anise, thyme and cumin compared to control sample.

Data in Table (5) indicates that the highest score of antioxidant activity were Cressina with cumin $(39.43 \pm 0.36)$ followed by thyme $(35.20 \pm 0.40)$ and anise $(32.30 \pm 0.12)$ compared to the control $(20.94 \pm 0.85)$. When comparing this result with the quantity of AA in the same samples it was obvious that 
cumin had the lowest score $(0.43 \pm 0.06)$ followed by anise $(0.48 \pm 0.05)$ then thyme $(0.54 \pm 0.03)$ and the highest score was in the control sample $(0.70 \pm 0.05)$. These results indicated that there were a significant increase $(p \leq 0.05)$ in antioxidants activities and a significant decrease $(\mathrm{p} \leq 0.05)$ in content of acrylamide among all samples.

In the present results in Table(5) analysis of antioxidant activity of Anise which concluded that Anise is an antioxidant agreed with the results of (Shojaii and Abdollahi., 2012) who reported that the most important compounds of anise seeds essential oil, aniseeds showed strong antioxidant activity, also agreed with those of (Ani et al., 2006; El-Ghorab et al., 2010; Nadeem and Riaz., 2012)who concluded that cumin have a good antioxidant potentiality and a good source of natural antioxidants As shown in Table (5) which concluded that Thyme is an antioxidant are in agreement with the result of Juki and Milo., 2005who reported that thyme exhibited varying amounts of antioxidative activity and it is a potential herbs having antioxidant activity and preservative effect. The previous results showed that, the highest percent of total antioxidant activity was found in Arabic bread with anise, thyme and cumin ,respectively compared to control sample while, the lowest content of acrylamide was found in bakery products when adding anise, thyme and cumin compared to control sample. These results approved that adding thyme. Cumin and anise increased antioxidants activity and decreased the content of acrylamide in bakery products.

These results are due to the chemical mechanisms of acrylamide formation in heated foods through Maillard reaction which are shown in figure (1). Acrolein (2-propenalCH2 $=\mathrm{CH}-\mathrm{CHO}$ ) is a three carbon aldehyde which is the back bone of acrylamide $\{\mathrm{CH} 2=\mathrm{CH}-\mathrm{C}(\mathrm{O})-\mathrm{NH} 2\}$. The antioxidants block the oxidation of acrolein to form acrylic acid thereby reducing the formation of acrylamide (Ciesarová et al., 2008). Acrole formed by transformation of lipids, degradation of amino acids and proteins degradation of carbohydrates and theMaillard reaction between amino acids or protein and carbohydrates. Thus lipid oxidation positively influenced the formation of acrylamide, especially in sugar-free system where lipids became the main sources of carbonyls, therefore antioxidants can inhibit acrylamide formation by preventing lipid oxidation, thus limit the acculation of carbonyls. So antioxidants can help protect acrylamide against radicals by scavenging them by changing the composition of the antioxidative extract during reaction. But if antioxidants is unstable or can be oxidized, it may attack acrylamide and reduce acrylamide content (Jin et al.,2013). That approved the relation between adding herbs and spices as antioxidants to reduce acrylamide formation.

Flavonoids,phenolics compounds and volatile oils (essential oils) of in some bakery products.

Analysis of flavonoids, total phenolics content and Volatile oils were conducted only on the samples that gained the highest score by panelists along with the controls sample.

Effect of adding thyme in Arabic bread, anise in Patonsalé and cumin in Cressina on the mean value of flavonoids, phenolic compounds and volatile oils as $\mathrm{mg} / 100 \mathrm{gm}$ are shown in Table(6).

Table 5: Antioxidant activity(\%) and acrylamide content $(\mathrm{mg} / \mathbf{1 0 0 g})$ in some bakery products.

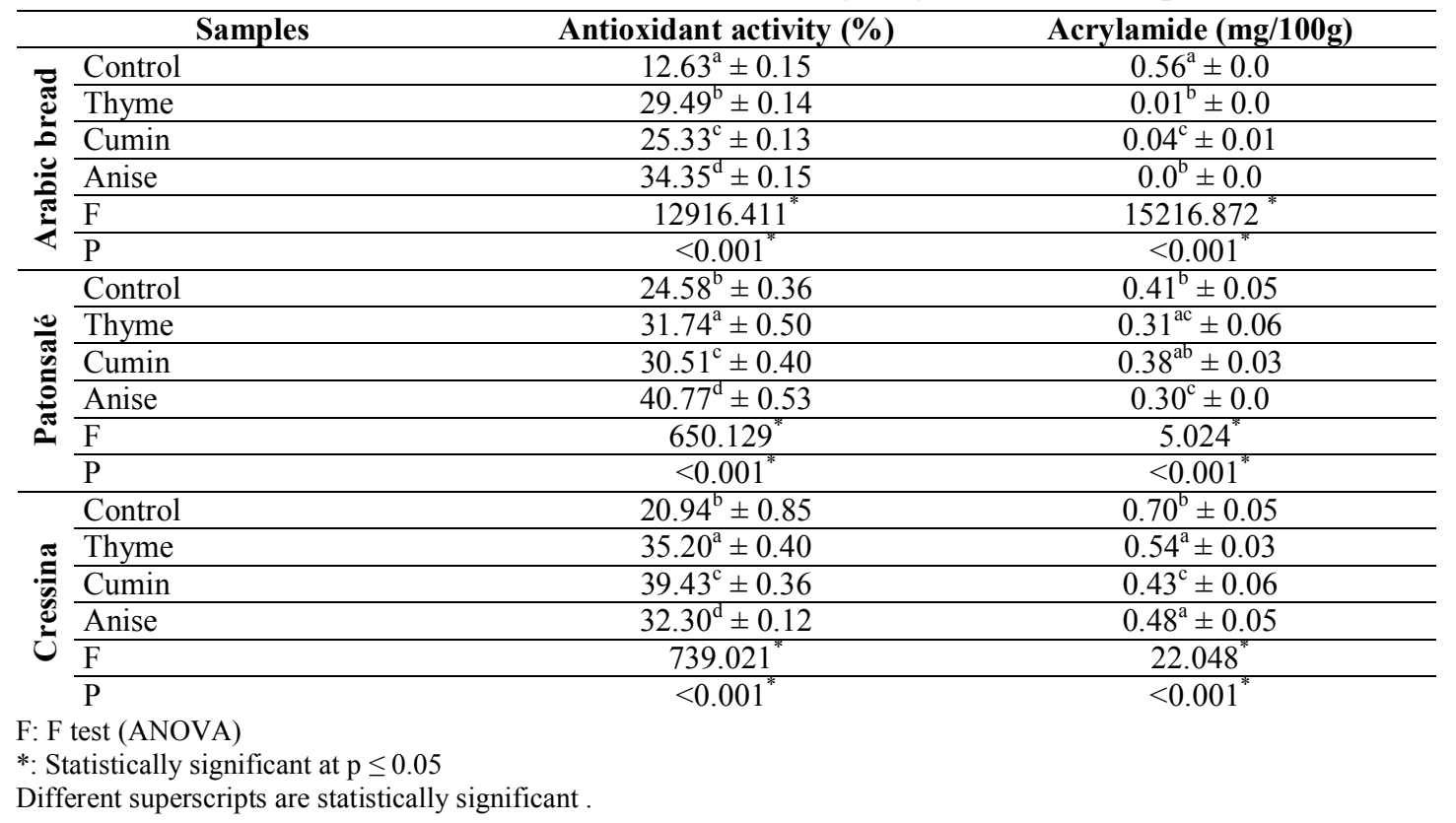


Table 6: flavonoids, phenolic compounds and volatile oil (essential oils) in selected bakery products.

\begin{tabular}{|c|c|c|c|c|c|c|}
\hline \multirow{2}{*}{ Samples } & \multicolumn{2}{|c|}{ (TVC) $\mathrm{mg} / 100 \mathrm{~g}$} & \multicolumn{2}{|c|}{ (TPC)mg/100g } & \multicolumn{2}{|c|}{ (EOs) (\%) } \\
\hline & Mean & \pm SD. & Mean & \pm SD. & Mean & \pm SD. \\
\hline Arabic bread with Thyme & $32.10^{\mathrm{b}}$ & 2.54 & $29.10^{\mathrm{e}}$ & 2.07 & $0.056^{\mathrm{d}}$ & 0.003 \\
\hline patonsale with Anise & $25.23^{\mathrm{cd}}$ & 2.79 & $77.04^{\mathrm{ab}}$ & 6.85 & $0.548^{\mathrm{a}}$ & 0.022 \\
\hline cressina with Cumin & $23.99^{\mathrm{d}}$ & 2.07 & $66.64^{\mathrm{c}}$ & 6.22 & $0.368^{\mathrm{b}}$ & 0.018 \\
\hline $\mathrm{F}$ & \multicolumn{2}{|c|}{$9.919^{*}$} & \multicolumn{2}{|c|}{$40.127^{*}$} & \multicolumn{2}{|c|}{$82.916^{*}$} \\
\hline $\mathrm{P}$ & \multicolumn{2}{|c|}{$<0.001^{*}$} & \multicolumn{2}{|c|}{$<0.001^{*}$} & \multicolumn{2}{|c|}{$<0.001^{*}$} \\
\hline
\end{tabular}

F: $\mathrm{F}$ test (ANOVA), *: Statistically significant at $\mathrm{p} \leq 0.05$, Different superscripts within a column are statistically significant.

It can be observed that the addition of spices and herbs to bakery product perform the highest significant TVC values and were detected in Arabic bread with Thyme $(32.10 \pm 2.54)$, while the lowest score was detected in Cressina with Cumin $(23.99 \pm 2.07)$ followed by Patonsalé with Anise $(25.23 \pm 2.79)$. The relation between the chemical structure of flavonoids and their radical scavenging activities is due to antioxidant activity of flavonoids depends on the structure of hydroxyl groups. The essential requirement for effective radical scavenging is the 3,4-orthdihydroxy configuration in ring $\mathrm{B}$ and 4- Carponyl group in ring $\mathrm{C}$. The presence of 3-and 5-OH groups, giving a catechollike structure in ring $\mathrm{C}$, is also beneficial for the antioxidant activity of flavonoids (Wojdylo et al.,2007).

It can be noticed in Table (6) that adding thyme, anise and cumin to salty samples bread, patonsalé, cressina also containing flavonoids compounds. Asignificant differences in the mean value of flavonoids among all samples were found.

The effect of adding thyme in Arabic bread, anise in patonsalé and cumin in Cressina on the mean value of phenolic compounds as $\mathrm{mg} / 100 \mathrm{~g}$ shown in Table (6). It can be noticed that the addition of thyme, cumin, anise to bakery products perform the highest significant of TPC values in Patonsalé with anise and Cressina with Cumin (77.04 \pm 6.85 and $66.64 \pm 6.22$, respectively) while, the lowest score was detected in Arabic bread with Thyme (29.10 \pm 2.07$)$. These results are agreement with those of (Allahghadri ., 2010) who showed that cumin with a high phenolic content and good antioxidant activity can be supplemented for both nutritional purposes and preservation of food. Adding cumin and anise to samples increased phenolics compounds.

This may be due to the high content of phenolic constituents and demonstrated good natural antioxidant activity. Besides, phenols are effective in inhibiting acrylamide formation, where aldehydic groups may increase the formation of acrylamide as reactive carbonyls, thus preparative methods of the antioxidant may influence acrylamide formation by changing the composition of the antioxidative extract during reaction (Jin et al., 2013). So adding herbs and spices under study decreased the formation of acrylamide.

Results shown in Table (6) indicates that the highest score of (EOs) in bakery products were detected in patonsalé with Anise $(0.548 \pm 0.022)$ followed by Cressina with Cumin $(0.368 \pm 0.368)$ while, the lowest score was detected in Arabic bread with Thyme $(0.056 \pm 0.003)$. The results from Table (6) summerized that the highest mean value of Eos compounds for Patonsalé with anise while, the lowest value was for thyme bread. There were significant differences in the mean value of EOs among all samples.

\section{CONCLUSION}

Thyme, cumin and anise have antioxidant potential and are recommended to be incorporated in bakery products. Further work is necessarily needed to explore the effect of using other herbs and spices in bakery products. Reducing Acrylamide in bakery products while protecting other quality aspects and reducing dietary AA exposure still remains a major challenge.

\section{REFERENCES}

Aaby K, Hvattum E. and Skrede G. (2004). Analysis of flavonoids and other phenolic compounds using high-performance liquid chromatography with coulometric array detection: Relationship to antioxidant activity. Journal of the Agricultural and Food Chemistry, 52, 4595-4603.

Agamy N, 2013, Pilot screening of acrylamide level in some Egyptian brands potato and corn products.Bulletin of Institute of Public Health, 43(1);13-21.

Allahghadri, T., Rasooli, I., Owlia, P., Nadooshan, M.J., Ghazanfari, T., Taghizadeh, M. and Astaneh, S.D. (2010). Antimicrobial property, antioxidantcapacity, and cytotoxicity of essential oilfrom cumin produced in Iran. Journal of Food Science, 75(2), H54-H61.

AniV, Varadaraj M C and Naidu K A. 2006. Antioxidant and antibacterial activities of polyphenolic compounds from bitter cumin (Cuminumnigrum L.). Eur Food Res Technol 224: 109-15. 
AOAC (Association of Official Analytical Chemists). (1995)). Official Methods of Analysis of AOAC Internation (17thed). Washington, D.C. Association of Official Analytical Chemists.

Bakare A H , Osundahunsi O F and Olusanya J O. 2016. Rheological, baking, and sensory properties of composite bread dough with breadfruit (ArtocarpuscommunisForst) and wheat flours. Food Science \& Nutrition; 4(4): 573-87.

Ciesarová Z, Suhaj M and Horváthová J.(2008). Correlation between acrylamide contents and antioxidant capacities of spice extracts in amodel potato matrix.Journal of food and Nutrition Research,47; 1-5.

Claus A, Carle R and Schieber A. (2008). Acrylamide in cereal products: A review. Journal of Cereal Science, 47, 118-33.

DjeridaneA, Yousfi M, Nadjemi B, Boutassouna D and Stocker P. N. 2006. Antioxidant activity of some Algerian medicinal plants extracts containing phenolic compounds. Food Chemistry, 97, 654-60.

Egan H, Kirk R.S and Sawyer R.1981. Pearson's chemical analysis of foods. $8^{\text {th }}$ ed. Churchill Livingstone Edinburgh London Melbourn and New York.

El-Ghorab A H, Nauman M, Anjum F M, Hussin $S$ and Nadeem M. 2010. A comparative study on chemical composition and antioxidant activity of ginger (Zingiberofficinale) and cumin (Cuminumcyminum). Journal of Agricultural and Food Chemistry 58, 82318237.

Friedman M.(2003). Chemistry, biochemistry and Safety of acrylamide.A review. Journal of Agricultural and Food Chemistrys, 51:4504-26.

Hussein A M S ,Kamil M M, Hegazy N A, Abo Elnor S A H. (2013). Effect of wheat flour supplemented with Barely and/or corn flour on balady bread quality. Food Nutrition.vol. 63 No 1, pp.11-18.

IARC. (1994). Acrylamide. In Some industrial chemicals. IARC Monographs on the evaluation of carcinogenic risk of chemicalsto humans. Lyon, France: International Agency for Research on Cancer.

Jin C,Wu X and Zhang Y.(2013). Relation between antioxidants and acrylamide formation: are view. Food Res. Int.; 51; 611-20.

Jooyandeh H. 2009. Evaluation of physical and sensory properties of Iranian Lavash flat bread supplemented with precipitated whey protein (PWP). African Journal of Food Science. Vol 3(2) pp. 028-34.
Juki, M. and Milo, M. (2005). Catalytic Oxidation and Antioxidant Properties of Thyme Essential Oils (Thymus vulgarae L.) CroaticaChemicaActa, 78 (1), 105-110.

Keramat J, LeBail A, Prost C and Jafari M. (2011). Acrylamide in Baking Products: A Review Article. Food and Bioprocess Technology, 4, 530- 43.

Khalaf Allah R.(2014). Acrylamide content in foods preferred by university students and reducing its level in fried foods and harmful effects on rats PHD in some economics, Faculty of Agriculture, Alexandria University.

Kirkpatrick L.A., and Feeney B.C. 2013. A simple guide to IBM SPSS statistics for version Student ed. Belmont, Calif.: Wadsworth, Cengage Learning 20.0.

Kotsiou K, Tasioula-Margari M, Capuano E, and FoglianoV. 2011. Effect of standard phenolic compounds and olive oil phenolic extracts on acrylamide formation in an emulsion system. Food Chemistry, 124, 242-247.

Kotz S, Balakrishnan N, Read C.B., and Vidakovic B. 2006. Encyclopedia of statistical sciences. 2nd ed. Hoboken, N.J.: Wiley-Interscience.

Lotfy T M R , Nawar I A. 2104. Codification of food and meals management. (In Arabic), Library of bostan el- maerefa. Kfrer- Eldawar

Makkar, H.P., Becker, K., Abel, H. and Pawelzik, E. (1997). Nutrient contents, rumen protein degradability and antinutritional factors in some colour- and whiteflowering cultivars of Viciafaba beans. Journal of the Science of Food and Agriculture, 75, 511-520.

Mills C, Mottram D S, Wedzicha B L. 2009. Acrylamide. In Process- InducedFood Toxicants, ed. RH Stadler, DR Lineback, pp: 23-50.

Mongi R J, Ndabikunze B K, Chove B E, Mamiro $\mathrm{P}$, Ruhembe $\mathrm{C} \mathrm{C}$ and tweny J G. 2011. Proximate composition, bread characteristics and sensory evaluation of cocoyam- wheat composite breads. AJFAND, Vol 11, No. 7, ISSN 1684-5374.

Nadeem $M$ and Riaz A. (2012). Cumin (Cuminumcyminum) as a potential source of antioxidants. Pakistan Journal of Food Sciences, 22(2), 101-07.

Okafor J N C, Okafor G I, Ozumba A U and Elemo G N. (2012). Quality characteristics of bread made from wheat and Nigerian oyster mushroom. Food Technology Divition, Pakistan journal of nutrition. ISSN 1680-5194.

Olaoye O A, Onilude A A and Idowu O A. 2006. Quality characteristics of bread produced from composite flours of wheat, plantain and soybeans. Afr. J. Biotech., 5(11): 1102-06. 
Ou S, Shi J, Huang C, Zhang G, Teng J, Jiang Y, and Yang B. 2010. Effect of antioxidants on elimination and formation of acrylamide in model reaction systems. Journal of Hazardous Materials,

182 , 863-868. DOI:10.1016/j.jhazmat.2010.06.124.

Saba, N.H. 1991 .Cooking is a science and art (In Arabic). Dar-ElMaaref. Three edition.

Shojaii A and AbdollahiFard M. (2012). Review of Pharmacological Properties and Chemical Constituents of Pimpinellaanisum. ISRN Pharmaceutics, 510795

SiddhurajuP, and Becker K. 2003. Antioxidant properties of various solvent extracts of total phenolic constituents from three different agroclimatic origins of drumstick tree (Moringaoleifera Lam.) leaves. J Agric Food Chem.; 51: 2144-55.

Stone H ,Bleibaum R N and Thomas H A. 2012. Sensory evaluation practices. Academic Press, Orlando, FL.
Williams B, Cuvelier W and Berset M E. 1995. Use of a free radical method to evaluate antioxidant activity. LebensmWiss Technol.; 28: $25-30$.

WojdyłoA, Oszmiański J and Czemerys R. 2007. Antioxidant activity and phenolic compounds in 32 selected herbs. Food Chem. 105: 940-9.

YasuharaA, Tanaka Y, Hengel M and ShibamotoT. (2003).Gas Chromatographic in vestigation of acrylamide formation in browning model system. Journal Agricultural and food chemistry, 51, 3999-4003.

Yildiz G and Bilgiçli N. 2012. Effects of whole buckwheat flour on physical, chemical, and sensory properties of flat bread, Lavaş. Czech J. Food.Sci., 30: 534-40.

Zaied SA ,Elgammal M, Mahmoud N.S. and AlkhalifahD, (2016). Effect of baking conditions and antioxidants on acrylamide content of biscuit. International Journal of Scientific Engineering and Applied Science, 2, 224-34.

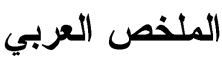

\section{تأثير الزعتر، الكمون، اليانسون علي تكوين الأكريلاميا في بعض المخبوزات \\ تسبي محمد رشاد لطفي'، نيفين فهمي محمد عجمي'، نيفين أحمد الورداني أحمد'، نشوة محمود يونس عبده'

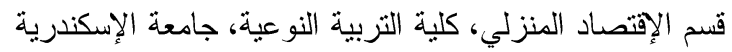

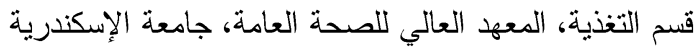

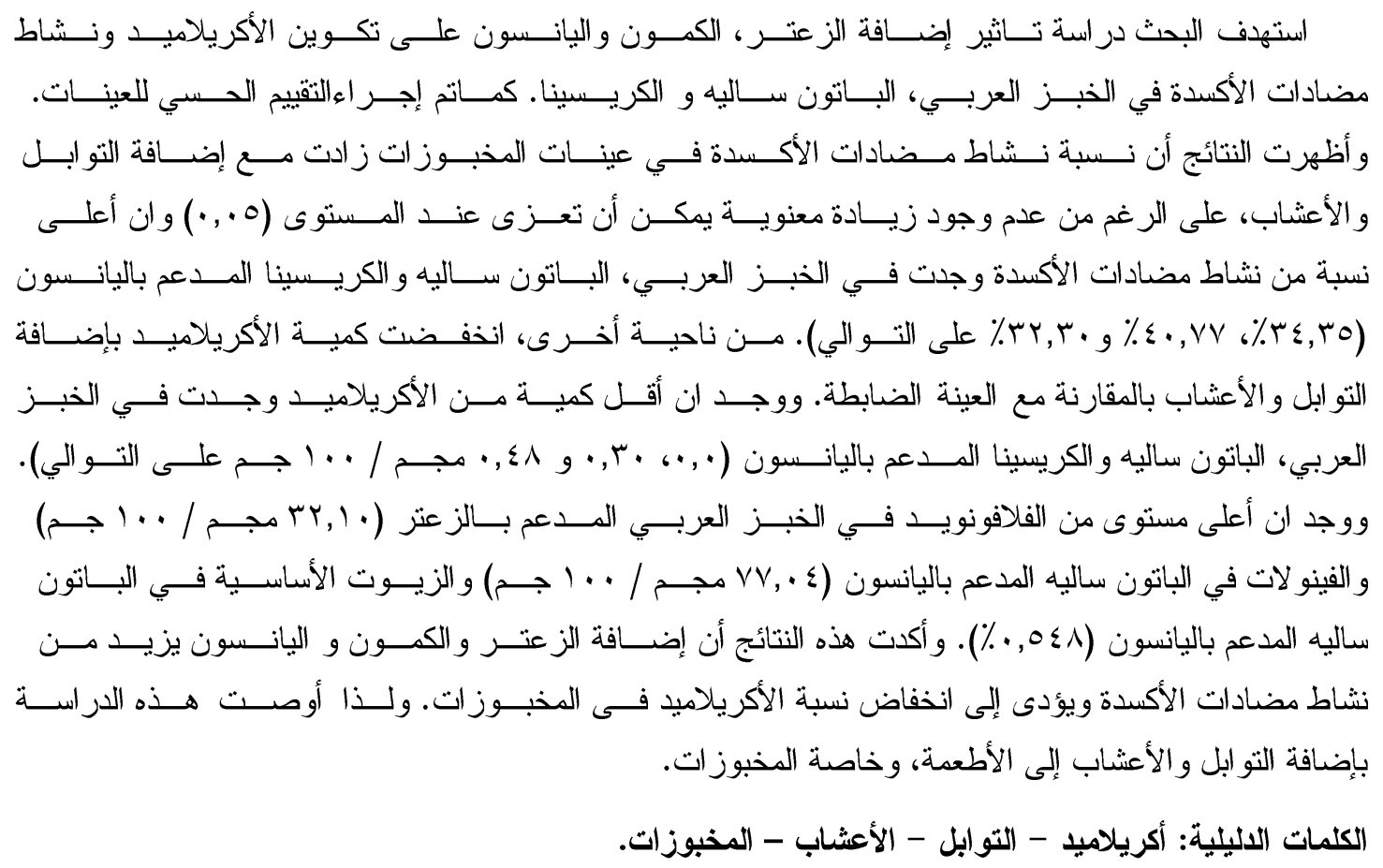

